\title{
SPATIAL VARIABILITY OF LEAF WETNESS DURATION IN COTTON, COFFEE AND BANANA CROP CANOPIES
}

\author{
Eduardo Alvarez Santos ${ }^{1}$; Paulo Cesar Sentelhas²*; José Eduardo Macedo Pezzopane; Luiz \\ Roberto Angelocci²; José Eduardo Boffino Almeida Monteiro \\ 'University of Guelph - Dept. of Land Resource Science, 50 Stone Road East - Guelph, Ontario, NIG 2W1, \\ Canada. \\ ${ }^{2}$ USP/ESALQ - Depto. de Ciências Exatas, C.P. 9 - 13418-900 - Piracicaba, SP - Brasil. \\ UFES/CCA - Depto. de Ciências Florestais - Jerônimo Monteiro, ES - Brasil. \\ *Corresponding author <pcsentel@esalq.usp.br>
}

\begin{abstract}
Despite the importance of leaf wetness duration for plant disease epidemiology, there has been little attention paid to research on how its variability relates to different cropping situations. The objective of this study was to evaluate the spatial variability of leaf wetness duration (LWD) in three crops, comparing these measurements with turfgrass LWD, obtained in a standard weather station. LWD was measured by electronic sensors in three crops with different canopy structures and leaf area: cotton, coffee and banana. For the cotton crop, cylindrical sensors were deployed at the lower third and on the top of the canopy, facing southwest. For the coffee crop, flat plate sensors were installed in the lower third of the canopy facing northeast and southwest; in the middle third facing northeast and southwest; and inside and on the top of the canopy. For the banana canopy, cylindrical sensors were used to measure LWD in the lower third of the canopy and in the upper third of the plant. Turfgrass LWD was simultaneously measured in a nearby standard weather station. The LWD showed different patterns of variation in the three crop canopies. For coffee plants, the longest LWD was found in the lower portions of the canopy; for the banana crop, the upper third of the canopy showed the longest LWD; whereas for the cotton crop no difference was observed between the top and lower third of the canopy. Turfgrass LWD presented a good relationship with LWD measured on the top or in the upper third of the crops. Thus, the estimate of crop LWD can be perfomed based on turfgrass LWD, this being a useful tool for plant disease management purposes for crops in which the longer LWD occurs at the upper canopy portion.
\end{abstract}

Key words: dew, microclimate, plant disease, warning systems

\section{VARIABILIDADE ESPACIAL DA DURAÇÃO DO PERÍODO DE MOLHAMENTO FOLIAR NAS CULTURAS DO ALGODÃO, DO CAFÉ E DA BANANA}

\begin{abstract}
RESUMO: Apesar da importância da duração do período de molhamento para a epidemiologia de doenças de plantas, pouca atenção tem sido dada à sua variabilidade em diferentes posições da cultura. O objetivo deste estudo foi avaliar a variabilidade espacial da duração do período de molhamento (DPM) em três culturas, comparando-se as medidas obtidas com a DPM medida sobre gramado em um posto meteorológico padrão. A DPM foi medida por sensores eletrônicos em três culturas com diferentes estruturas de dosséis e áreas foliares: algodão, café e banana. Na cultura do algodão, os sensores cilídricos foram instalados no terço médio e no topo do dossel voltados para o sudoeste. Na cultura do café, sensores de placa foram instalados no terço inferior do dossel voltados para nordeste e sudoeste; no terço médio também voltados para nordeste e sudoeste; no interior e no topo do dossel. Na cultura da banana, sensores cilíndricos foram instalados nos terços inferior e superior da planta. A DPM sobre gramado foi simultaneamente medida em um posto meteorológico próximo às culturas. A DPM exibiu diferentes padrões de variação nas três culturas. Para o cafeeiro, a DPM mais longa foi observada nas partes mais baixas da planta; para a bananeira, o terço superior foi o que apresentou a maior DPM; enquanto que para a cultura do algodão não houve diferença entre o topo e o interior do dossel. A DPM medida sobre gramado apresentou boa correlação com a DPM medida no topo ou no terço superior das culturas. Dessa forma, pode-se estimar a DPM nas culturas a partir da DPM do gramado, sendo esta uma ferramenta muito útil para o manejo de doenças de plantas em culturas onde a DPM mais longa ocorre nas porções superiores do dossel.

Palavras-chave: orvalho, microclima, doenças de planta, sistemas de alerta
\end{abstract}

Sci. Agric. (Piracicaba, Braz.), v.65, special issue, p.18-25, December 2008 


\section{INTRODUCTION}

Leaf wetness duration (LWD) is an important factor in plant disease epidemiology since the persistence of free water over plant surfaces plays an essential role in some epidemiological processes such as infection and sporulation (Huber \& Gillespie, 1992). LWD is not considered to be a true meteorological variable, as it is not only dependent on meteorological conditions but is also related to physical properties of plant surfaces and crop characteristics, such as leaf area, plant structure, crop systems or plant distribution in the field, and plant height, due to changes in the microclimate (Madeira et al., 2002; Monteith \& Unsworth, 1990).

Microclimate variables drive the processes of condensation and evaporation of water on vegetal surfaces. Therefore, microclimatic conditions control wetness duration, allowing various portions of leaves and canopies to become wet and dry at different times, consequently leading to a spatial variability of LWD measurements (Huber \& Gillespie, 1992). This spatial variability is an important aspect to be considered when measuring LWD in crops. In previous studies, measurements have been carried out just below or on the top of crop canopies (Francl \& Panigrahi, 1997; Pedro \& Gillespie, 1982; Sentelhas et al., 2004b). However, some authors show that the LWD spatial variability changes from one crop to another. Wittich (1995) observed that LWD was longer at the top than at the bottom of an apple canopy. Sentelhas et al. (2005) showed that LWD lasted one hour longer at the top of apple and maize canopies than at the bottom; but no difference was found between LWD measured at different positions of young coffee plants and grape canopies.

These differences in LWD values have some practical implications in disease warning systems. Using the Plasmo model to simulate grapevine downy mildew severity, Dalla Marta et al. (2004) observed that estimated severity using LWD data obtained inside the canopy was lower than the actual severity, whereas the use of LWD data obtained outside the canopy led to a disease severity overestimation.

Sentelhas et al. (2005) proposed to estimate the longest LWD in crop canopies using LWD data obtained in nearby standard weather stations. Their results showed that by using this approach it is possible to obtain estimates reasonable enough for disease warning systems. Another advantage of this methodology is to solve operational problems related to the measurements of LWD in crops.

Considering the importance of spatial variability of LWD for plant disease occurrence and control, the objective of this study was to assess LWD spatial variability in three crops with different structures and leaf area, comparing these measurements with LWD obtained in a standard weather station.

\section{MATERIAL AND METHODS}

The field experiments were carried out in Piracicaba, São Paulo State, Brazil (2243' S, 47³0' $\mathrm{W}, 546 \mathrm{~m})$. The LWD was measured using electronic sensors: flat plate (Model 237, Campbell Scientific, UT, USA) and cylindrical sensors (Weather Innovations Inc., ON, Canada). Both types of LWD sensors were painted with white latex paint in order to increase their sensitivity to moisture as well as to simulate leaf optical properties, following the recommendations of Gillespie \& Kidd (1978) and Sentelhas et al. (2004a).

Before being used in the field, all LWD sensors were set up over turf grass in order to determine a resistance threshold for each sensor to be considered wet and also to ensure that all sensors were working properly. The flat plate sensors were mounted on PVC tube sections and deployed at $45^{\circ}$ in relation to the horizontal plane. Sentelhas et al. (2004b) observed that LWD measurements obtained by flat plate sensors deployed at this position over turfgrass and maize had a good agreement with visual observations of wetness. The cylindrical sensors were attached to adjustable-angle clamps at $15^{\circ}$ since they have shown good agreement with flat plate sensor measurements when deployed at this angle (Santos, 2006). After this, the sensors were installed in three crops with different canopy structures and leaf area: cotton, coffee and banana (Figure 1).

For the cotton crop, the measurements were taken from November 29, 2005 to February 14, 2006, totaling 78 days. The LWD was obtained by cylindrical sensors deployed at $15^{\circ}$. The sensors were installed perpendicularly to the crop rows facing southwest in the lower third and at the top of the canopy (Figure 1 ). The height of the sensors was continuously adjusted to follow plant growth. During this period cotton crop leaf area index (LAI) varied from one to three. The sensors were connected to a data logger (SIMAD, Autsens, SP, Brazil) which recorded their averages at 15 min intervals, which were used to calculate the proportion of the time that each sensor was wet.

LWD measurements in the coffee crop, with approximately four years old, rows oriented northwestsoutheast and row spacing of $3.5 \mathrm{~m}$, were preformed from April 1 to June 23, 2006, totaling 74 days. The sensors were installed in a plant of $1.6 \mathrm{~m}$ height and leaf area of $4.2 \mathrm{~m}^{2}$ per meter of the hedgerow at six different positions (Figure 1): at the lower third of the 


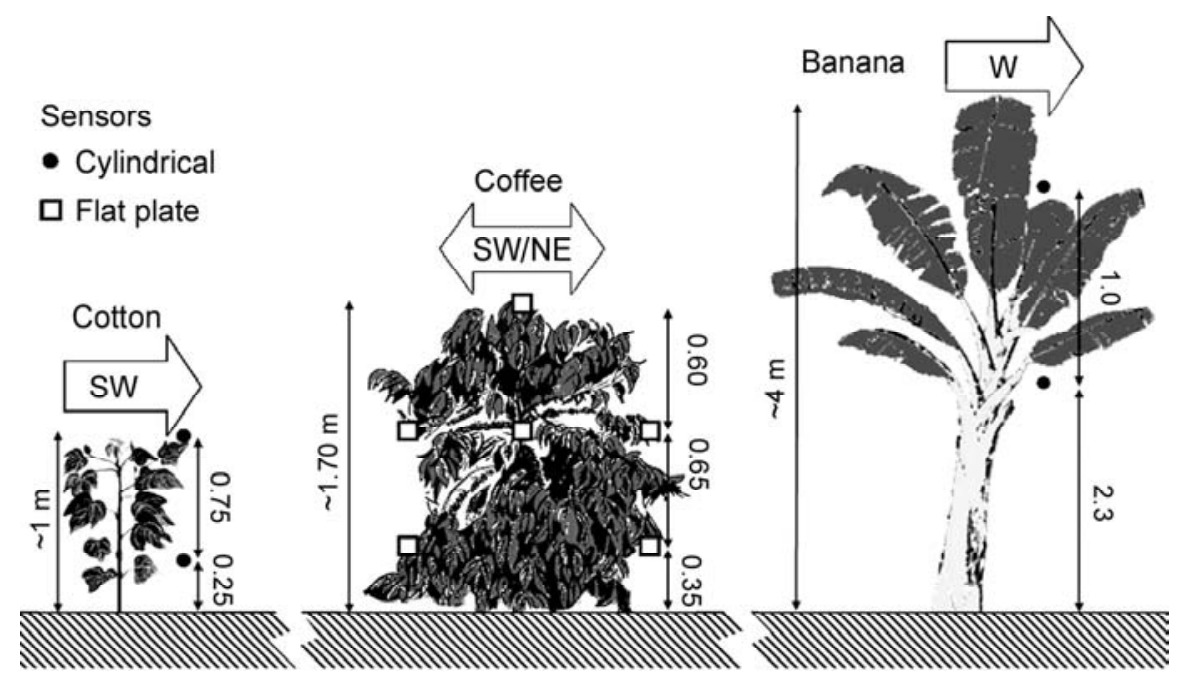

Figure 1 - Diagram with the positions and expositions of the leaf wetness duration sensors for the evaluated crops: cotton, coffee and banana.

canopy, at $0.35 \mathrm{~m}$ height; on both sides of the plant; at the middle third, at one meter, on both sides and in the interior of the canopy; and at $1.65 \mathrm{~m}$ height on the top of the canopy. At each position LWD was measured using two flat plate sensors, deployed at $45^{\circ}$. The sensors were installed close to the leaves on both sides of the plant, and oriented northeast and southwest. They were connected to a data logger (CR7, Campbell Scientific, UT, USA) which provided histograms with the proportion of time for which each sensor was wet at $15 \mathrm{~min}$ intervals.

For the banana crop, with LAI $=6$, with rows oriented north-south and row spacing of three meters, LWD measurements were obtained from May 30 to July 13, 2006, totaling 45 days, at two different positions: the lower third of the canopy, at $2.3 \mathrm{~m}$ height, close to the insertion of the first leaf; and in the upper third of the plant, at $3.3 \mathrm{~m}$ height, close to the upper surface of the highest leaves (Figure 1). The cylindrical sensors were deployed at $15^{\circ}$ facing west. The sensors were connected to a data logger (CR10, Campbell Scientific, UT, USA), which provided histograms with the proportion o time for which each sensor was wet.

Simultaneously, LWD was also measured in nearby standard weather stations, located always less than two kilometers from the crops. This distance was not a problem for comparisons since the area is homogeneous in terms of microclimate allowing the weather station to represent the standard conditions for the whole area. Two flat plate sensors were mounted on PVC tube sections and deployed at $45^{\circ}$ facing south, $30 \mathrm{~cm}$ above turf grass canopy. Pedro Junior (1980), Lau et al. (2000) and Sentelhas et al. (2004b) observed that LWD measurements obtained by flat plate sensors deployed at this posi- tion presented good agreement with visual observations of LWD over turfgrass, with errors smaller than 30 minutes. Thus these measurements were used as reference for comparisons with crop LWD. In addition to LWD measurements, rainfall was also measured during the experiments using a tipping bucket rain gauge (TE525WS-L, Texas Electronics, TX, USA).

The LWD was totaled for 24-hour periods, starting at $12 \mathrm{~h} 15$ of day " $\mathrm{n}$ " and finishing at $12 \mathrm{~h} 00$ of day " $n+1$ ". LWD data, obtained at different canopy positions were compared using the mean absolute difference (MAD) which indicates the magnitude of the mean difference, and using the mean difference (MD), which describes the direction of the bias:

$$
\begin{gathered}
M A D=\frac{\sum_{i=1}^{n}\left|x_{i}-x_{T}\right|}{n} \\
M D=\frac{\sum_{i=1}^{n}\left(x_{i}-x_{T}\right)}{n}
\end{gathered}
$$

where: $x_{i}$ is the LWD onset and dry-off times at different canopy positions, $x_{T}$ is the LWD onset and dryoff times at the top canopy and $\mathrm{n}$ is the number of observations.

The relationships between turfgrass LWD and crop LWD in different canopy positions were obtained using regression analysis. The significance of the regression analysis coefficients was determined by a ttest $(p<0.05)$. The models obtained by the regression analysis were compared using the identity test proposed by Regazzi (1993). This analysis determines whether the coefficients obtained for two curves are statistically different. 


\section{RESULTS AND DISCUSSION}

LWD presented different patterns of variation for the three crop canopies (Table 1). For cotton no difference was observed between the mean LWD measured at the top and lower third of the canopy. On the other hand, for coffee, differences were noticed among mean daily LWD values obtained at different canopy positions. The sensors installed at the lower positions of the coffee canopy and facing southwest generally had longer LWD than sensors installed at the top of the plant. Mean daily LWD measured inside the coffee canopy was also $1 \mathrm{~h}$ longer than the LWD obtained at the top of the plant. For banana the mean LWD at the upper third of the canopy was $1.9 \mathrm{~h}$ longer than the LWD measured at the lower third of the plant.

The results for cotton may be related to the fact that LWD was measured for the initial crop phases, when the leaf area was small and sensors were close to each other leading to similar values of LWD. However, for the coffee crop the top of the canopy was more exposed to wind and solar radiation, reducing the dew deposition during the night and leading to faster drying-off during the day. Similar results were found by Sentelhas et al. (2005) who observed that LWD was $1.5 \mathrm{~h}$ longer at the lower third than at the top of young coffee plants, with approximately $80 \mathrm{~cm}$ height. For banana, the occurrence of shorter LWDs at the lower third of the canopy may be related to differences in the net radiation at these canopy positions, as a consequence of high LAI. The sensors installed in the canopy were partially covered by leaves which intercepted the long wave radiation during night, causing a slower cooling of the sensors, which resulted in the deposition of small amounts of dew over their surfaces (Dalla Marta et al., 2004).

The canopy exposure was also an important factor for the LWD variability. The sensors located at the middle third of the coffee plant, facing southwest, generally measured longer LWD $(1.3 \mathrm{~h})$ than those sensors facing northeast. At the lower third, the effect of the exposure was not so evident, which is probably related to the shadow caused by plants in adjacent rows as well as by the leaves that partly covered the sensors. The effect of the exposure of the canopy on LWD has also been reported by Dalla Marta et al. (2004), who observed the longest LWD in the west face of a grape canopy.

A more detailed analysis of the LWD spatial variability can be provided by the differences between the wetness onset or dry-off times in different parts of the canopy (Table 2). For the cotton crop, the wetness onset at the top occurred on average $16 \mathrm{~min}$ before the onset at the lower third of the canopy, whereas the dry-off was on average measured 4 min later in the canopy. However, the differences between those positions were not significant, considering the errors inherent in the LWD measurements and observations (Pedro Junior, 1980; Magarey, 1999).

For coffee, the wetness onset was observed later at the top than at the other parts of the canopy (Table 2). The largest mean difference (DM) observed for the onset was between the top and the lower third of the plant facing southwest, where the wetness onset occurred on average $101 \mathrm{~min}$ earlier than at the top. The mean absolute difference (MAD) for the wetness onset ranged from 44 to $118 \mathrm{~min}$, with an average of $78 \mathrm{~min}$. The wetness dry-off was generally measured later inside than for other positions outside the canopy. The sensors installed at the lower third of the plant facing southwest had the dry-off occurring 118 min later than for the sensors installed at the top

Table 1 - Average leaf wetness duration (LWD) at different positions of cotton, coffee and banana canopies, in Piracicaba, SP, Brazil.

\begin{tabular}{llc}
\hline Crop & Position & LWD $(\mathrm{h})$ \\
\hline \multirow{2}{*}{ Cotton $(\mathrm{n}=78)$} & Top & 9.1 \\
& Lower third & 9.1 \\
\hline & Top & 12.3 \\
& Inside & 13.3 \\
Coffee $(\mathrm{n}=74)$ & Middle third NE & 12.7 \\
& Lower third NE & 14.0 \\
& Middle third SE & 14.0 \\
& Lower third SE & 14.1 \\
\hline \multirow{2}{*}{ Banana $(\mathrm{n}=45)$} & Upper third & 16.1 \\
& Lower third & 14.2 \\
\hline
\end{tabular}

$\mathrm{n}=$ number of assessed days

Table 2 - Mean difference (MD) and mean absolute difference (MAD) among wetness onset and dry-off times at different positions of coffee canopy, using as a reference onset and dry-off times obtained at the top of a coffee plant, in Piracicaba, SP, Brazil.

\begin{tabular}{lcccccc}
\hline \multirow{2}{*}{ Position* } & \multicolumn{2}{c}{ MD (min) } & & \multicolumn{2}{c}{ MAD (min) } \\
\cline { 2 - 3 } \cline { 5 - 6 } & Onset & Dry-off & & Onset & Dry-off \\
\hline MT_NE & -41 & -1 & & 44 & 18 \\
INS & -64 & -11 & & 77 & 32 \\
LT_NE & -88 & 13 & & 104 & 21 \\
MT_SW & -48 & 74 & & 50 & 75 \\
LT_SW & -101 & 84 & & 118 & 85 \\
\hline Average & -68 & 32 & & 78 & 46 \\
\hline
\end{tabular}

"MT_NE = middle third facing NE; INS = inside the canopy; LT_NE = lower third facing NE; MT_SW = middle third facing SW; LT_SW = lower third facing SW. 
of the canopy; those sensors also presented the latest dry-off. The MAD for the dry-off ranged from 18 to $85 \mathrm{~min}$ with an average of $46 \mathrm{~min}$.

The occurrence of wetness onset earlier at the lower portions and inside the plant is probably related to lower wind speed at these positions, which contributed to a faster dew formation. In addition, the lower parts of the canopy were closer to the soil, which is an important source of water vapor for the dew formation process (Rosenberg et al., 1983). On the other hand, the top and the northwest canopy side were more exposed to solar radiation, which is the main reason for the faster wetness dry-off observed at these canopy positions. It was expected that the sensors located inside the canopy would record the dryoff later than the sensors located outside the canopy, as they were less exposed to solar radiation. However, it is probable that a smaller amount of dew was deposited on the plant surfaces inside the canopy, leading to an earlier dry-off inside the canopy. On the opposite, the lower parts of the canopy and those facing southwest were less exposed to the solar radiation leading to a late wetness dry-off. When measuring the LWD at different positions of a tomato canopy, Lau et al. (2000), noticed that sensors facing east had the wetness dry-off 20 min later than the sensors facing north, south and west.

For banana, the wetness onset at the upper third of the canopy occurred 96 min earlier than at the middle third. The MAD between these positions was 99 min. The wetness dry-off occurred on average 24 min earlier at the middle third than at the upper third of the canopy. The MAD for the dry-off between the two positions was $38 \mathrm{~min}$. Similar results were observed by Wittich (1995), who reported longer LWD at the top of apple trees than at the bottom of the canopy. Sentelhas

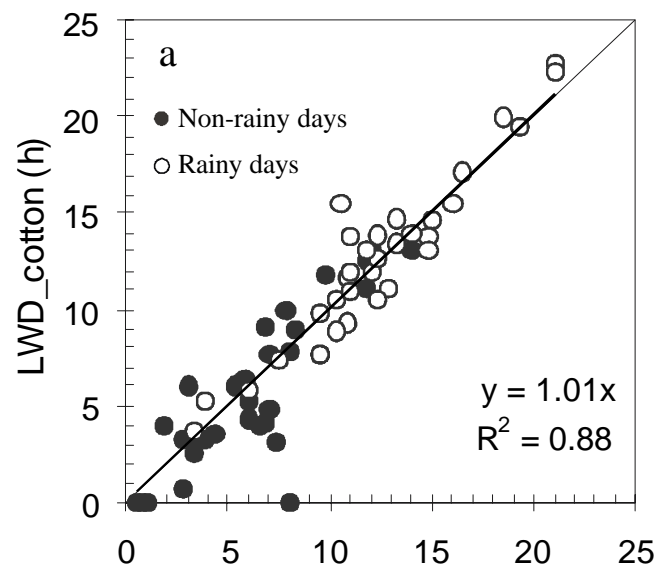

et al. (2005) also found longer LWD for apple trees, ranging from $8.7 \mathrm{~h}$ for the top to $6.8 \mathrm{~h}$ for the lower third of the canopy, and for maize plants, from $14.5 \mathrm{~h}$ for the top to $13.5 \mathrm{~h}$ inside the canopy. The results found for the banana crop apparently disagree with what was found for coffee in this study; however it is necessary to consider that the highest sensors in the banana crop were installed at the middle third of the canopy, under upper leaves, instead at the top. Therefore the sensors were affected by the foliage, which reduced the wind speed and sunshine in this position, leading to higher values of LWD.

The agreements between turfgrass LWD and crop LWD, obtained for the upper canopy portions, were high. All coefficients, obtained using regression analysis, were significant by t-test $(\mathrm{p}<0.05)$. There was a broader range of values of LWD for cotton as compared to the other crops (Figure 2). This is related to the fact that the measurements in cotton were carried out during the rainy season when the occurrence of longer LWD was usual. On the other hand, short nights with higher temperatures and low relative humidity contributed to the occurrence of short LWDs. The relationships between turfgrass LWD and crop LWD resulted in coefficients of determination of 0.89 for the top and 0.82 for the lower third of the canopy. The slope of the regression showed that LWD in the lower third of the cotton crop was about 3\% higher than the LWD obtained over turfgrass, while the difference between the LWD on the top and over turfgrass was less than $1 \%$. The identity model test showed that regression coefficients for both equations were not different by the F-test $(p<0.05)$. Therefore, the relationship between turfgrass and crop LWD, measured at the top or at the lower third of the canopy, can be represented by one single equation.

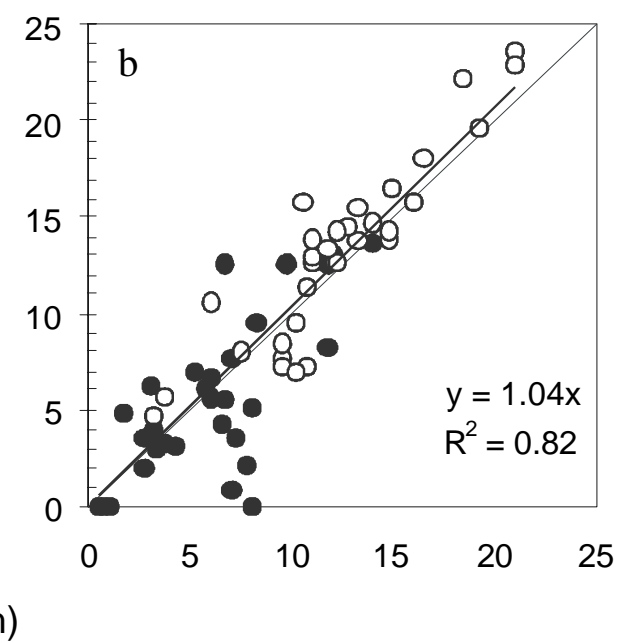

Figure 2 - Relationship between leaf wetness duration (LWD) measured over turfgrass in a standard weather station and at the top (a) and at the lower third (b) of a cotton canopy, in Piracicaba, SP, Brazil. 
Considering that the measurements for cotton were carried out during the initial crop phases, with small LAI, these results were expected since the sensors in the canopy and those over turfgrass were installed at similar heights and exposures. On the other hand, the lower precision of this relationship at the lower third of the crop, expressed by the $R^{2}=0.82$, can be caused by the shading effect on the sensors by the foliage.
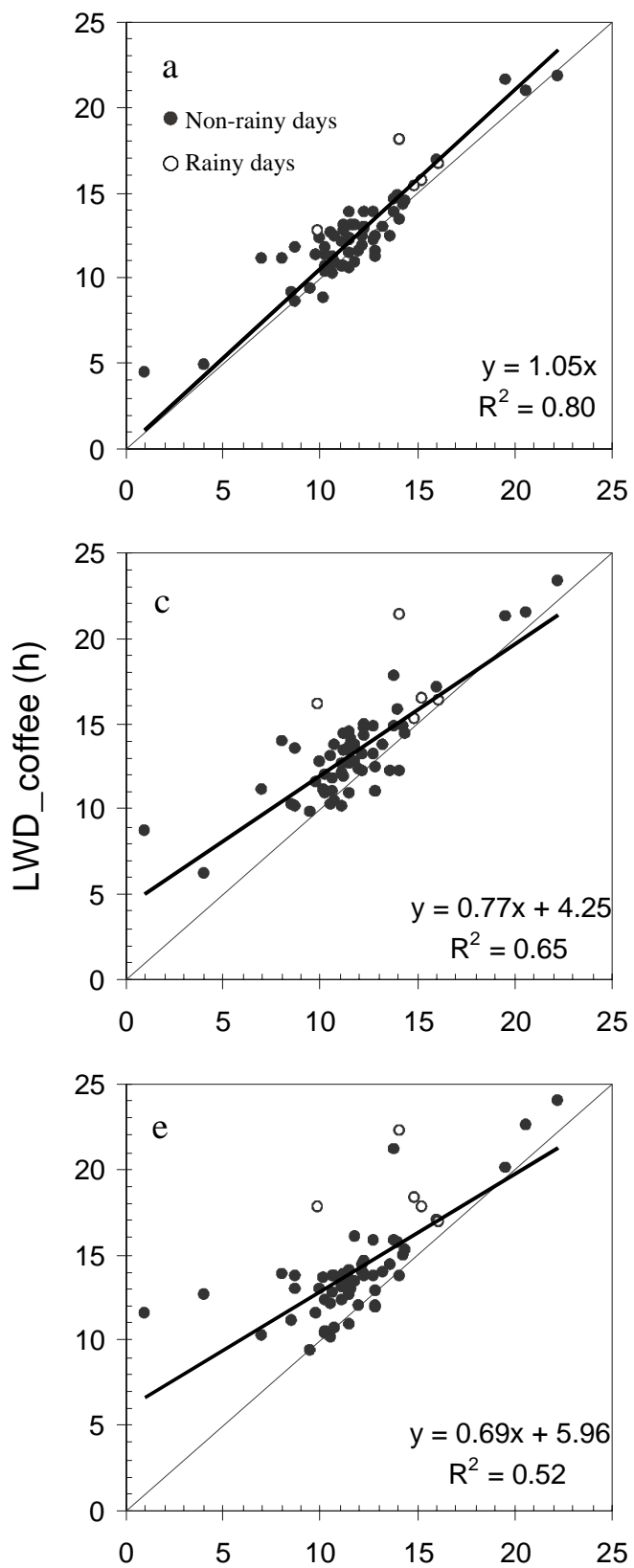

For the coffee crop, the relationship between turfgrass and crop LWD presented $\mathrm{R}^{2}$ values ranging from 0.80 at the top of the crop to 0.52 for the middle third facing southwest (Figure 3). The identity model test indicates that the regression coefficients obtained for the top, middle third facing $\mathrm{NE}$ and inside the canopy were not different by the F-test $(p<0.05)$. However, the coefficients obtained for the top were different from those obtained for the other canopy po-
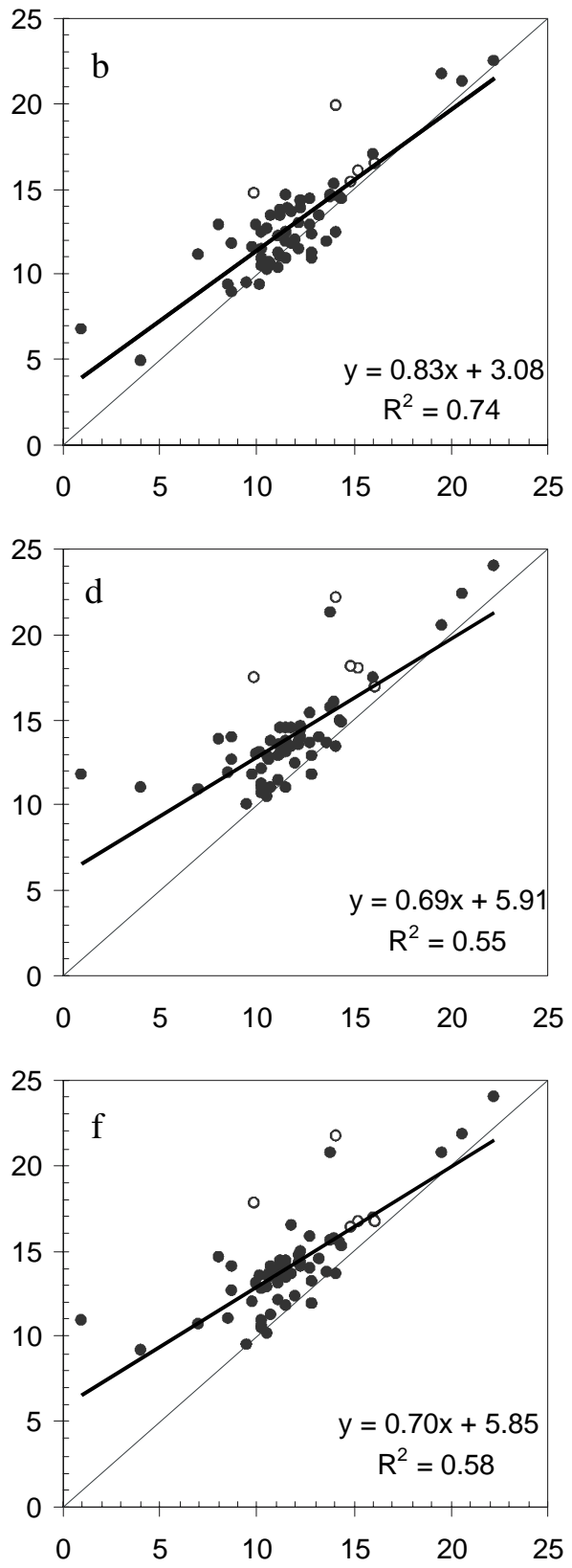

LWD_grass (h)

Figure 3 - Relationships between leaf wetness duration (LWD) measured over turfgrass in a standard weather station and obtained at different positions of a coffee canopy: top (a), middle third facing NE (b); inside the canopy (c); lower third facing NE (d); middle third facing SW (e); lower third facing SW (f), in Piracicaba, SP, Brazil.

Sci. Agric. (Piracicaba, Braz.), v.65, special issue, p.18-25, December 2008 


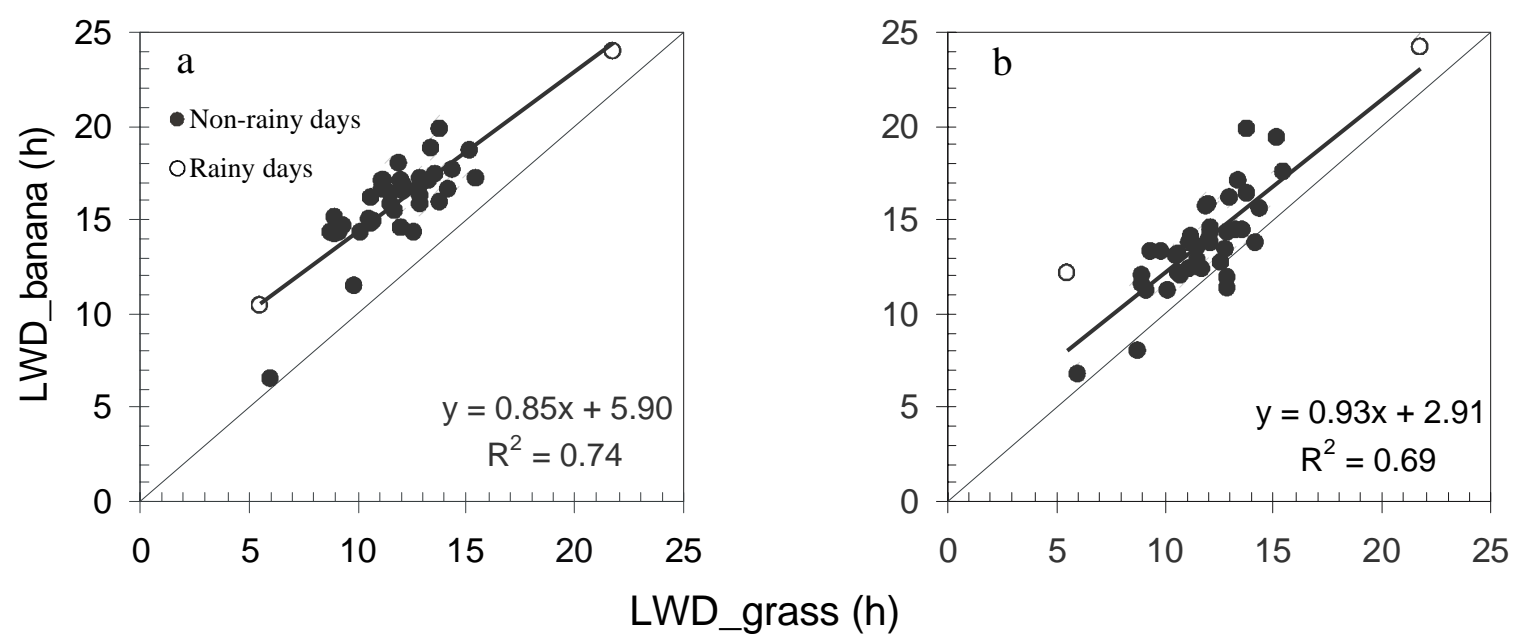

Figure 4 - Relationship between leaf wetness duration (LWD) measured over turfgrass in a standard weather station and at the upper third (a) and lower third (b) of a banana canopy, in Piracicaba, SP, Brazil.

sitions (middle third facing SW, lower third facing NE and lower third facing SW).

In general, the LWD measured in the coffee canopy was longer than that over turfgrass in the nearby weather station. The LWD at the top of the coffee plant was around 5\% longer than that over turfgrass. For the other positions, turfgrass LWD was smaller than crop LWD for turfgrass wetness duration below $20 \mathrm{~h}$ and greater than that for turfgrass LWD higher than $20 \mathrm{~h}$. Such trends make it more difficult to adopt a single linear correction factor for estimating crop LWD from turfgrass LWD. In this case it is necessary to use more complex models as mentioned by Sentelhas et al. (2005).

As observed for the other crops, the best relationship between turfgrass and crop LWD for banana was obtained for the top of the canopy, with a $\mathrm{R}^{2}$ of 0.74 (Figure 4). At this position, the crop LWD was systematically longer than that of the turfgrass whereas for the middle third of the crop, the difference was smaller, but with a greater data dispersion, with a $\mathrm{R}^{2}$ of 0.69 . The coefficients of the relationship between turfgrass and banana LWD were not different by the F-test $(p<0.05)$.

LWD was affected not only by meteorological conditions but also by canopy characteristics, as for example plant height, plant architecture, leaf exposition and leaf area, whose interaction determines the crop microclimate. The relationships between the turfgrass LWD measured at the weather station and the crop LWD measured at the upper canopy positions, showed that is possible to use electronic sensors installed at weather stations in a reference position to estimate LWD for different crops, as also observed by Sentelhas et al. (2005). However, further studies re- lated to the spatial variability of crop LWD and its estimation from turfgrass LWD are required to ensure the accuracy of this technique for other crops.

\section{REFERENCES}

DALLA MARTA, A.; ORLANDINI, S.; GHIRONI, M.; SABATINI, F. Influence of different sensor positions on leaf wetness measurements and their effect on the simulation of grapevine downy mildew (Plasmopara viticola). Idõjárás, v.108, p.253263, 2004

FRANCL, L.J.; PANIGRAHI, S. Artificial neural network models of wheat leaf wetness. Agricultural and Forest Meteorology, v.88, p.57-65, 1997.

GILLESPIE, T.J.; KIDD, G.E. Sensing duration of moisture retention using electrical impedance grids. Canadian Journal of Plant Science, v.54, p.179-187, 1978.

HUBER, L.; GILLESPIE, T.J. Modeling leaf wetness in relation to plant disease epidemiology. Annual Review of Phytopathology, v.30, p.553-577, 1992.

LAU, Y.F.; GLEASON, M.L.; ZRIBA, N.; TAYLOR, S.E; HINZ, P.N. Effects of coating, deployment angle, and compass orientation on perfomance of electronic wetness sensors during dew periods. Plant Disease, v.84, p.192-197, 2000.

MADEIRA, A.C.; KIM, K.S; TAYLOR, S.E.; GLEASON, M.L. A simple cloud-based energy balance model to estimate dew. Agricultural and Forest Meteorology, v.111, p.55-63, 2002.

MAGAREY, R.D. A theoretical standard for estimation of surface wetness duration in grape. Ithaca: Cornell University, 1999. 208p. (Ph.D.).

MONTEITH, J.L.; UNSWORTH, M.H. Principles of environmental physics. 2 ed. New York: Routledge, 1990. $291 \mathrm{p}$.

PEDRO JUNIOR, M.J. Relation of leaf surface wetness duration to meteorological parameters. Guelph: University of Guelph, 1980. 147p. (Ph.D.).

PEDRO JUNIOR, M.J.; GILLESPIE, T.J. Estimating dew duration I. Utilizing micrometeorological data. Agricultural Meteorology, v.25, p.283-296, 1982.

REGAZZI, A.J. Teste para identidade de modelos de regressão e igualdade de alguns parâmetros num modelo polinomial ortogonal. Revista Ceres, v.40, p.176-195, 1993.

ROSENBERG, N.J.; BLAD, B.L.; VERMA, S.B. Microclimate: the biological environment. New York: John Wiley, 1983. 495p. 
SANTOS, E.A. Duração do período de molhamento foliar: medida com sensores eletrônicos, variabilidade espacial em culturas e estimativa com modelos empíricos. Piracicaba: USP/ESALQ, 2006. 56p. (Mestrado).

SENTELHAS, P.C.; MONTEIRO, J.E.B.A.; GILLESPIE, T.J. Electronic leaf wetness duration sensor: why it should be painted. International Journal of Biometeorology, v.48, p.202-205, $2004 \mathrm{a}$.

SENTELHAS, P.C.; GILLESPIE, T.J.; BLATZER, J.C.; GLEASON, M.L.; MONTEIRO, J.E.B.A; PEZZOPANE, J.R.M.; PEDRO JUNIOR, M.J. Spatial variability of leaf wetness duration in different crop canopies. International Journal of Biometeoroly, v.49, p.363-370, 2005.
SENTELHAS, P.C.; GILlESPIE, T.J.; GLEASON, M.L.; MONTEIRO, J.E.B.A.; HELLAND, S.T. Operational exposure of leaf wetness sensors. Agricultural and Forest Meteorology, v.126 p.59-72, 2004b.

WITTICH, K.P. Some remarks on the dew duration on top of an orchard. Agricultural and Forest Meteorology, v.51, p.145$158,1995$.

Received November 01, 2007

Accepted June 16, 2008 